\title{
特別寄稿 鍼炎医療におけるインフォームド・コンセント
}

\author{
植西憲達 熊田知浩 高橋剛士 生駒晃彦 \\ 青柳信寿 濱洲晋哉 野元 進 \\ 京都大学医学部
}

\author{
Informed Consent in Acupuncuture and Moxibustion
}

$\begin{array}{lll}\text { Norimichi UENISHI } & \text { Tomohiro KUMADA } & \text { Tuyoshi TAKAHASHI } \\ \text { Akihiko IKOMA } & \text { Nobuhisa AOYAGI } & \text { Sinya HAMASU } \\ \text { Susumu NOMOTO } & & \end{array}$

Faculty of Medicine, Kyoto University

\section{I 、はじめに}

現在、我々は医学を学んでいるが、医学は西洋 医学のみでないことをよく理解している。インド の伝統医学・アーユルヴェーダ、中国に起源を発 する鍼炎・湯液・導引・按矯といった東洋の医学 などリがそれである。そこで、代替医療という テーマを設定し、特に日本において明治時代まで 医学の主流を占めていた東洋医学に的を絞り、銊 尒医療を調查研究の対象とした。

東洋医学は、(1)現代医学の治療の仕方と異なり、 病人の自然治瘾力を高める、(2)病気の状態を『証」 の概念でパ夕ーン化し、証に従って治療する2)。 そこで、最初に東洋医学とは如何なるものか、鍼 炎で疾病治療をどのように行うのか、本当に効く のかなど、素朴な疑問を抱きつつ明治鍼炎大学で 鍼炎治療を体験し、鍼炎医学の概要と鍼炎研究の 現状に関する講義・説明を受けた。

この最中に、 1 つの事件がスポーツ新聞の 1 面 を賑わし、我々は大変驚かされた。それは、プロ 野球・読売ジャイアンツの槙原寛己投手が鍼治療 で気胸を患ったという報道である. 槙原投手は春 先より右肩痛治療のため右肩甲骨周辺に鍼を行 い、低周波電流を流す鍼通電とマッサージ療法を 受けていた。7 月11日、鍼の深刺で胸膜に穴が開
き、気胸と診断され入院した。

鍼尒や漢方などの東洋医学では、副作用や医療 過誤が少ないということが一般にはよく知れわた っているところであり、東洋医学の長所の 1 つた と思ってきた我々はこの事件に驚き、それがきっ かけとなって銊炎治療における過誤や副作用がど れくらいあるのかを調べた。その結果、過誤や副 作用は意外と多く(図1)、訴訟に発展したケースも あることがわかった(図2)

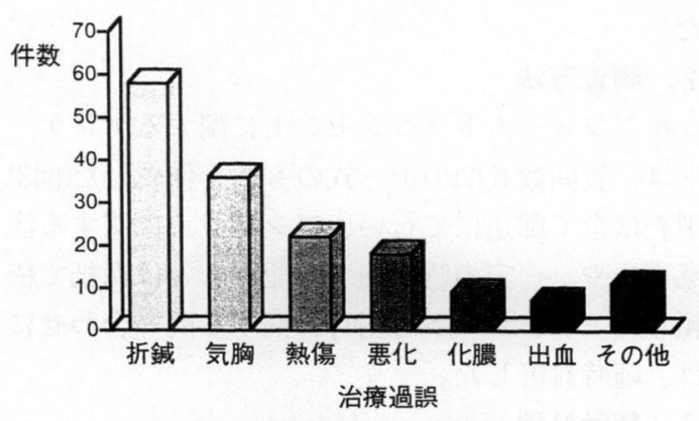

図1鍼炎医療にみる治療過誤

これらのことから今回、鍼炎医療ではインフ オームド・コンセント（医療過誤や副作用などに ついて訴訟の多い西洋医学では一部の例外一癌告 知などーを除いて当たり前になってきている）4 は行われているのか、医療過誤や副作用が発生し

* \%606 京都市左京区吉田近衛町 京都大学医学部 $\mathbf{\mathbf { 0 } 0 7 5 - 7 5 3 - 4 3 0 0}$

Faculty of Medicine, Kyoto University, Konoe-cho Sakyo-ku, Kyoto 606, Japan 
た場合を想定してどの様な対策をしているのかを 調べる目的でアンケートを作成し、調査を行い若 干の知見を得た。

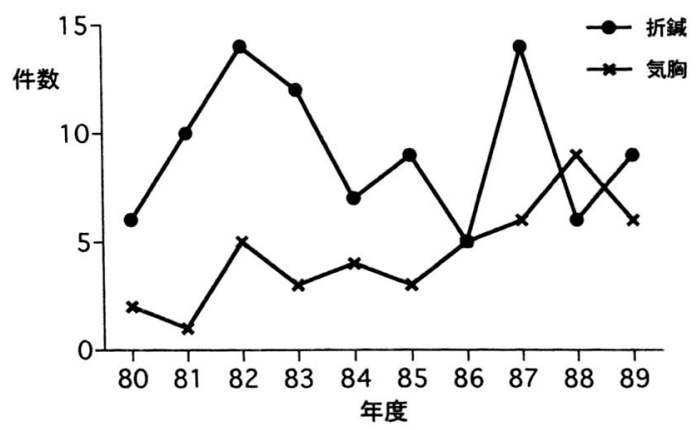

図2日銊会系年度別医事紛争件数

\section{II. 対象と方法}

\section{1. 対 象}

京都府内で鍼炎治療に従事する明治銊尒大学卒 業の若手鍼炎師計141名（男性113名、女性28名／ 平均年齢28.6歳）を対象とした。対象者には調査 内容を説明し、同意を得て協力を願った。鍼炎の 勤務形態は病院勤務、銊尒院勤務、開業の 3 種類 に区分した。勤務形態別の比較にあたっては、回 収後の人数が少ないものに限って追加調査を加え た。

\section{2. 調查方法}

インフォームド・コンセントに関するアンケー トは、質問数 6 問の択一式のものを作成した(図3) 調査は全て郵送にて行い、アンケートに関する注 意事項や、一定の時間内での記載などは別紙で依 頼した。アンケートの内容に関する問い合わせに は、随時対応した。

\section{3. 統計処理}

米マイクロソフト社製統計ソフト・Microsoft Excel Ver.5と米アバカスコンセプト社製Stat view-J4.02を用いて統計処理を行った。

\section{III. 結 果}

\section{1.アンケート結果}

\section{1 ）対象者の勤務形態}

対象者の勤務形態を図 4 に示す。勤務形態は病 院勤務が31\%、鍼炎院勤務が33\%、開業鍼炎師が
銊炎治療におけるインフォームド・コンセントに関する

$$
\text { アンケート調査 }
$$

以下の質問に答えて下さい（丸印もしくは文章で）

京都大学医学部
1。あなたの年齢・性別は
年齢
性別
2.あなたの銊炎医としての立場は何ですか $\mathrm{A}$ 病院勤務 $\mathrm{B}$ 銊尒院勤務 $\mathrm{C}$ 開業 $\mathrm{D}$ その他
3.インフォームド・コンセントについて知っていますか $\mathrm{A}$ 言葉もその内容も知っている
B 言葉は知っているが、内容はよくわからない C 知らない

$$
\text { インフォームト゚・コンセントとは基本的に }
$$

「医師が患者によく病状を説明し、それに応じた検査・治療について十 分な情報を提供し、患者はそれについて十分理解し承諾した上で誰に も強制されない自由な立場で検査や治療法を選び取り、その同意に基 づいて医師が治療を行う。ということを意味します。

4.鐵炎医療においてインフォームド・コンセントは必要と考えますか Aはい Bいいえ Cわからない

4’.4でいいえと答えた場合はその理由を選んで下さい $\mathrm{A}$ 鍼尒医療では重大な副作用は起こり得ない B患者が求めていない Cその他

5.鍼炎医療に扔いてインフォームド・コンセントを行っていますか Aはい Bいいえ Cわからない

5’，5ではいと答えた場合はどのように行っていますか $\mathrm{A}$ 同意書などの書類を取ることもあるＢ口答でのみ行う Cその他 (

5". 5でいいえと答えた場合はその理由を選んで下さい $\mathrm{A}$ 鍼炎治療を患者が理解できるように説明するのは困難である Bインフォームド・コンセントを行うだけの時間がない C必要がないからＤその他（

6. あなたは今後銊尒医療においてインフォームド・コンセントはど の様になっていくと考えますか

A 拡大していく B 現状のまま C わからない Dその他（） 以上で質問は終わりです。ご協力ありがとうございました。

図 3 アンケート用紙

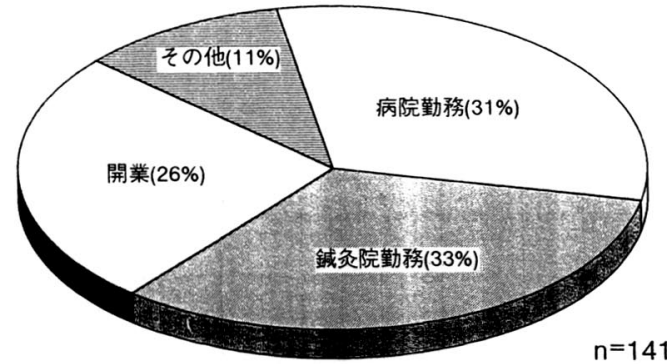

図 4 対象者の勤務形態

$26 \%$ あった。その他とした11\%は、鍼炎師免許 を持つ学生・教員・研究者である。

2 ）インフォームド・コンセントに関する理解 （全体）

図 5 は『インフォームド・コンセントを知って いますか』の問に対する全体の結果を示す。言葉 
も内容も知っている人が $82 \%$ 、言葉は知っている が内容を理解していない人が $17 \%$ 、言葉も内容も 理解していないと答えた人が1\%であった。

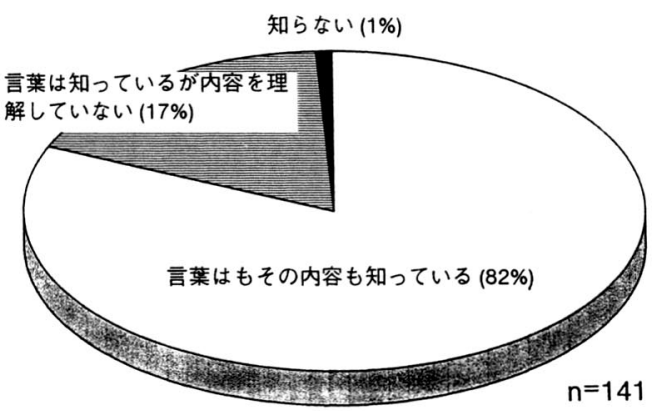

図 5 インフォームド・コンセントに関する理解（全体）

\section{3 ）インフォームド・コンセントの勤務形態別} 理解度

勤務形態別にみた『インフォームド・コンセン トを知っていますか』の問に対する結果を図 6 に 示す。『言葉も内容もよく知っている」と答えた 人は病院勤務者では $80 \%$ 、銊尒院勤務者では $89 \%$ 、 開業者では72\%であった。病院勤務、鍼尒院勤務 では『知らない』と答えた人はいなかったが、開 業では $3 \%$ 人が知らないと答えた。

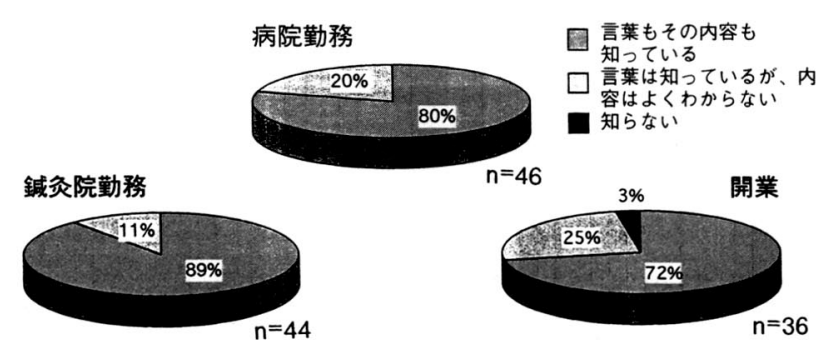

図 6 インフォームド・コンセントの勤務形態別理解度

\section{4 ) インフォームド・コンセントの必要性}

図 7 は『鍼尒医療においてインフォームド・コ ンセントは必要と考えますか』の問に対する全体 の結果を示す。『必要である」と答えた人が77\%、 『必要でない」が15\%、『わからない』が $8 \%$ \%で った。

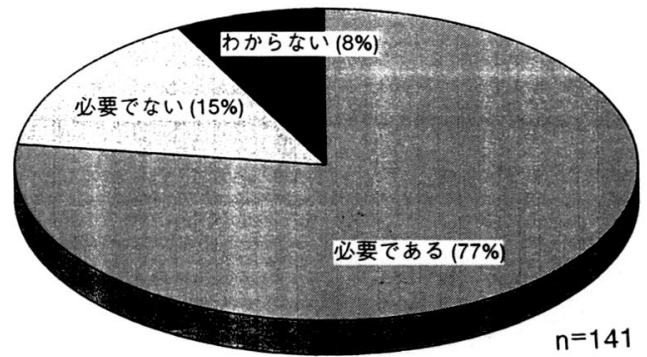

図 7 イインフォームド・コンセントの必要性

5）インフォームド・コンセントの勤務形態別 必要性

勤務形態別にみた『鍼尒医療においてインフ オームド・コンセントは必要と考えますか』の問 に対する結果を図 8 に示す。病院勤務と鍼炎院勤 務では『必要である』が82\%、『必要でない』が 11\%、『わからない』が7\%であった。開業では 『必要である』が67\%、『必要でない』が25\%、 『わからない』が $8 \%$ であり、病院勤務や鍼尒院 勤務に比してインフォームド・コンセントの必要 性を感じていない鍼尒師が多くみられる結果が示 された。

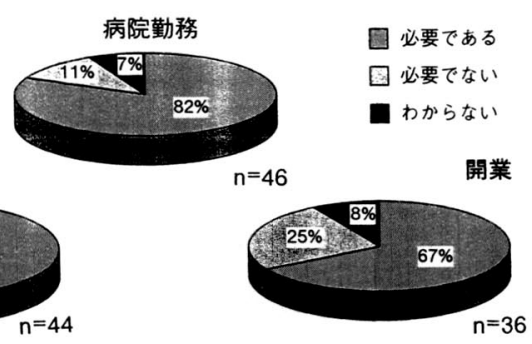

図 8 インフォームド・コンセントの勤務形態別必要性

6) インフォームド・コンセントが必要でないと 答えた理由

必要でないと回答した人に、『銊尒医療でイン フォームド・コンセントが必要でない理由』を求 めた結果、『重大な副作用は起こり得ない』が $47 \%$ 、『患者が求めていない』が29\%、『その他』 が $24 \%$ あっった（図9）。『その他』と答えた人で は、（生死に直結するような）重篤な事態を招く 治療を行っていない等の理由があった。 


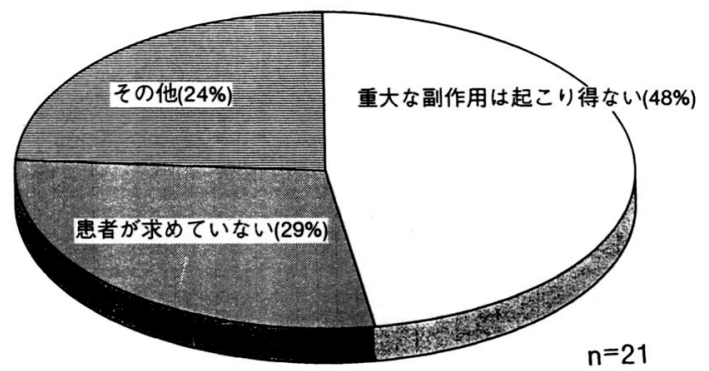

図 9 インフォームド・コンセントが必要でないと答えた理由

\section{7 ）インフォームド・コンセントの実施の現状}

図10は『インフォームド・コンセントを行って いますか』の問に対する全体の結果を示す。『は い』と答えた人は55\%、『いいえ』と答えた人は 45\%であった。

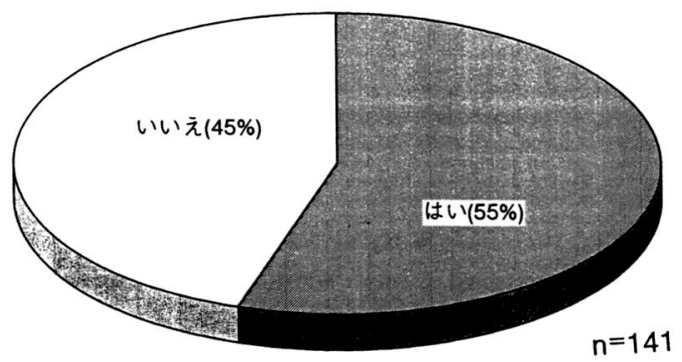

図10 インフォームド・コンセントの実施の現状

病院勤務

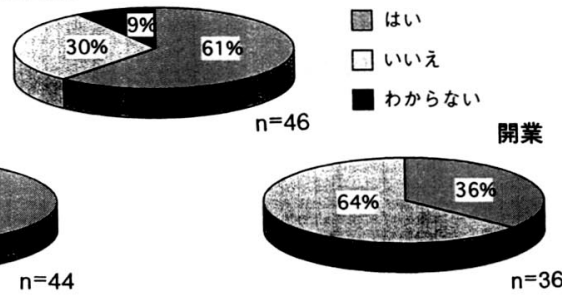

図11 インフォームド・コンセントの勤務形態別実施状況

\section{8 ）インフォームド・コンセントの勤務形態別} 実施状況

勤務形態別にみた『インフォームド・コンセン

トを行っていますか』の問に対する結果を図11に 示す。『はい』と答えた人は病院勤務が $61 \%$ 、銊
尒院勤務が57\%、開業が36\%であり、『いいえ』 と答えた人は病院勤務が30\%、銊尒院勤務が39\%、

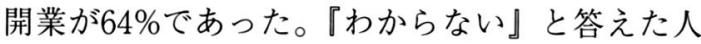
は病院勤務が $9 \%$ 、鍼尒院勤務が $4 \%$ 、開業が 0\%であった。

\section{9) インフォームド・コンセントの行い方}

行っていると答えた人に、『インフォームド . コンセントをどの様に行っていますか』と問うた 結果を図12に示す。『口答でのみ行う』と答えた 人が $94 \% 、 『$ 同意書などを取ることもある』と答 えた人が $6 \%$ \%゙った。同意書などを取ることも あると答えた $6 \%$ のは大学の教員、大学院生、 研究者で主に臨床研究の了解に関するものであっ た。

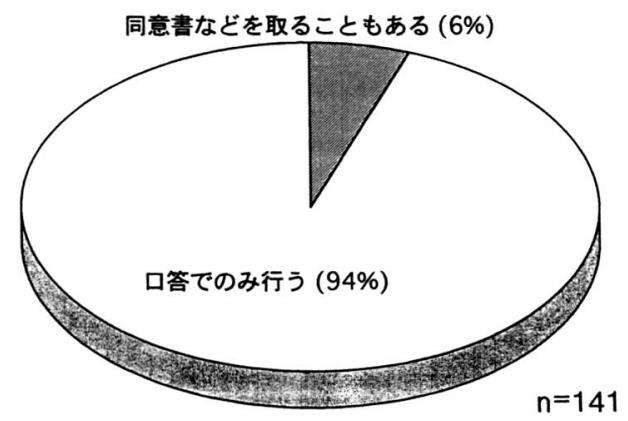

図12 インフォームド・コンセントの行い方

10）インフォームド・コンセントを行っていない 理由

行っていないと答えた人に、『インフォーム ド・コンセントを行わない理由』を問うた結果を 図13に示す。『説明が困難』と答えた人が $34 \%$ 、 『時間がない』と答えた人が $32 \%$ 、『必要がない』

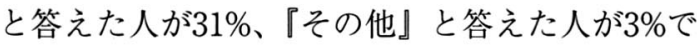
あった。

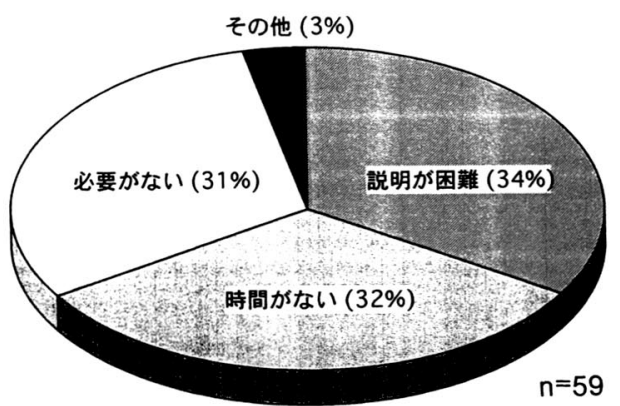

図13 インフォームド・コンセントを行なっていない理由 


\section{1）インフォームド・コンセントの展望}

銊尒界における『インフォームド・コンセント の今後の展望』を問うた結果を図14に示す。『拡 大していく』と答えた人が70\%、『現状のまま』 と答えた人が $14 \%$ 、『わからない』と答えた人が 16\%であった。

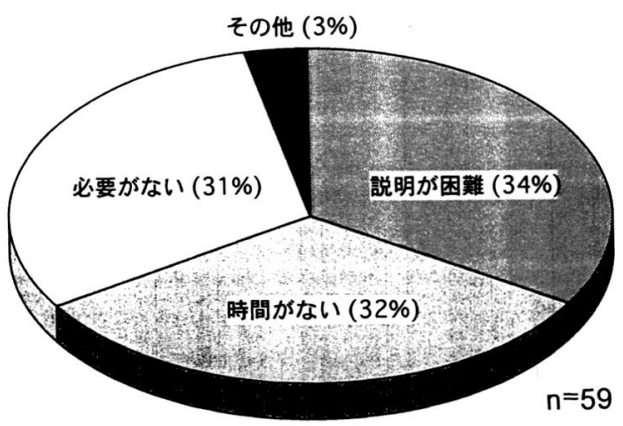

図14 インフォームド・コンセントの今後の展望

\section{N. 考 察}

インフォームド・コンセントの必要性を感じつ つも実際に行っていない理由として『説明困難 (55\%)』、『時間がない(44\%)』という理由が大多数 を占めていた。インフォームド・コンセントを行 う時間を求めるのは、本当に困難なことだろうか。 銊炎医療では、西洋医学で行うような大がかりな 検査を行わずに望診・聞診・問診・切診を中心に 患者の個人情報を入手し、診察・治療にあたる。 （法的に）診療器具が限定されていることから診 察で患者と話し、情報を得ることにもかなりの時 間をかけている。このような診療上の特徴は、意 識や時間配分の工夫次第で困難事情の一部を解消 できることを十分に意図すると感じる。他方、 （調査を通じて）説明困難や時間がないと答えた 人の中には、実際は面倒くさいや習慣がないとい ったケースがあるようにも思われた5)。必要ない からと答えた人は、医療過誤の実態や訴訟の話を どのようにとらえているのであろうか。今後の課 題としたい。また、本調査で対象の $82 \%$ $\%$ インフ オームド・コンセントを知っていると答えたが、 （理想的には）全ての人の共通理解であることが 望まれる。
インフォームド・コンセントを行う上で『同意 書をとる』の $6 \%$ は、大学の教員·犬学院生・研 究者が、主に実験の了解を得るときと答えている ことから、実際の治療では全て口答で行われてい ると考える。確かに鍼尒では生死に関わるような ことがないだろうという視点からはいたしかたな いことかもしれないが、生命に関わるかどうかと いうことと、患者に説明し同意を求めることは別 の問題だと思われる。患者が求めていないからイ ンフォームド・コンセントをしなくてよいのか、 という問題と合わせて鍼炎における倫理観の基本 コンセプトの必要性を感じる。この点については、 生死に直接関わる機会の薄い医師達(歯科医など) がどのようにとらえているかも調べてみる必要が ある。

一般に病院勤務の銊尒師は、インフォームド・ コンセントに関して一番意識が高かった。病院勤 務ではともに働いている医療従事者からの影響も あり、一緒に治療にあたるうえでインフォーム ド・コンセントを行う必要性を意識する機会が多 いためと思う。銊尒院勤務では、言葉の理解度が 高いのに実際に行っている割合が低いのは（一面 で）このことを裏付けていると考える。

他方、開業鍼尒師のインフォームド・コンセン トの意識はそれほど高くなかった。今回の対象と した開業銊尒師は 1 人で治療を行っており、(周 囲に医療従事者がいる他の 2 者と比べ）治療上の 全ての決定権を自分自身が握っていること、まわ りの目を気にしなくて良いなどの背景因子が自ら のインフォームド・コンセントの意識を低くして いる理由にあるようにも思われた。

今後、インフォームド・コンセントがどのよう になっていくかについて、70\%の人が『拡大して いく』と考えている。また、インフォームド・コ ンセントを行っていないという人でも $42 \%$ が将来 拡大していくと答えている。将来の拡大は、今の 鍼炎師の方々の努力によるところが大きいと思 う。この視点からは現在をもっと考える必要があ るのではないだろうか。 


\section{V. まとめ}

最近、患者も医師のいうなり、という時代から 患者自身が医療を選ぶ時代にきており、鍼尒医療 をはじめとする東洋医学の需要も疼痛を扱うペイ ンクリニックを中心に高まっている。そのため鍼 尒師をおく病院も増えており、今後の医療現場で は我々も看護婦、技師、social worker のみなら ず銊尒師の方々とも治療に当たったり、患者を鍼 炎院に紹介したりする機会が増えると思われる。

今回の調査では、鍼尒師のインフォームド・コ ンセントに対する意識はまだ十分に高くないとい うことが示唆された。臨床のみならず、鍼尒教育 を含めた全体的なインフォームド・コンセントの 取り組みの高揚、ひいては医学界全体の高揚を望 む次第である。

\section{謝 辞}

本研究の調査に際し、ご協力・ご助言をいただ いた明治銊尒大学大学院の尾崎昭弘教授、矢野 忠教授をはじめ明治銊尒大学の諸先生方、数々の ご助言をいただいた京都大学医学部衛生学教室の 糸川嘉則教授、木村美恵子助教授に対して感謝を 表します。

\section{文 献}

1) $\mathrm{WHO} / \mathrm{R}$ ，バンナーマンほか編著、津谷喜一 郎訳：世界伝統医学大全. 第 1 版第 1 刷、平 凡社、東京、1995.

2 ) 野元 進: 証の研究. 東方医学雑誌、12(2): $1 \sim 21 、 1996$.

3 ）鍼炎治療における安全性ガイドライン委員会 編：銊尒治療における感染防止の指針. 医歯 薬出版、第 1 版第 1 刷、東京、 1993.

4) 笹子三津留：がん医療におけるインフォーム ド・コンセント。第24回日本医学会総会会 誌、I : 24、1995.

5 ）日本医師会 生命倫理懇談会編：「説明と同 意」に関するアンケート集計結果報告書、日 本医師会、東京、12-16、1990. 